TranscUlturAl, vol.1,3 (2010), 30-42.

http://ejournals.library.ualberta.ca/index.php/TC

\title{
The Unbearable Torment of Translation: Milan Kundera, Impersonation, and The Joke
}

Miriam Margala
University of Rochester

Kundera's message to his translators - or to any translator for that matter - is clear: "You're not in your own house here, my dear fellow". Friends or not, my house is my house; my work is my work. In his "Author's Note" in the 1996 edition of his novel Žert (The Joke), Kundera comments on his feelings upon reading his works in translation in a pithy manner: "rage seized me". Serious, intense and harsh. Are not all the translators trying to do their best to bring foreign works to new readers? Are they not working hard, oftentimes feeling trapped between Scylla and Charybdis, trying to find a solution that would be liked by both monsters? And then, however tough the fight, the translator stands (mostly) invisible. Kundera's Czech works (he has been writing in French for some years now) are completely embedded in their cultural, political, social and geographical contexts - Kundera's translators must become close friends with both Scylla and Charybdis to navigate those treacherous waters! That's what translators do and they certainly do like a challenge. But what if the most challenging problem presents itself as the author of the original? Not to be welcome in the author's house and to learn that the author rages upon reading the work of translators must feel very defeating. I read Kundera's words again: "this is my house, not yours ... rage seizes me at what I see happening in my house" ... Many of us are familiar with these words - they are very similar to the words God says to the moneychangers inside his house/his temple. The context may be different, but Kundera's stance is not all that different. He is the author, he is the father/creator of the text, it belongs to him, he controls it. In short, Kundera impersonates God in the context of his works and their translations. I will also suggest that this ownership manifests itself as an organic unity between Kundera and his works in that Kundera is his work. He fears this unity will become severed in translations of his works. Thus, he becomes completely involved, omnipresent in the process of translation of his works to ensure that even these translations (especially French and English since he speaks both) truly are his, and only his, authentic word. As a result, Kundera's involvement and control changes completely the usual "original then translation" progression. Thus, I also propose that in this particular case, it is rather counterproductive to think in terms of “original” and "translation" as Kundera demands that his works, in whatever language, bear 
TranscUlturAl, vol.1,3 (2010), 30-42.

http://ejournals.library.ualberta.ca/index.php/TC

the same authenticity as his Czech works. In the case of the definitive English and French versions, his own involvement and signature validate these versions. The history and path of Kundera's works and their translations is, indeed, filled with contradictions and controversy but by exploring Kundera's less quoted thoughts on his work, expression and obsession with translation, I hope to illuminate his viewpoint and disposition. Mr. Kundera will no doubt continue to be the omnipresent god-like figure in his own house, but by connecting dots that may not have been connected yet I may be able to reveal the impetus behind Kundera's posture.

Is my proposition of Kundera impersonating God intense, serious, over the top? Based on literature written on Kundera, on available interviews and his essays, I suspect Kundera would readily agree with me. In the recent article in The Observer (April 25, 2010) Tim Parks accentuates this theocratic notion when he cites Kundera: "The translator's "supreme authority", Kundera thundered in Testaments Betrayed, "should be the author's personal style ..." (my emphasis). In his essays, Kundera discusses literature, authorship and novel in particular. One of the authors he mentions in his discussions is James Joyce. Here, I find it particularly fitting to briefly mention a not-so-well known story of James Joyce's Finnegans Wake and its translation into Czech. Czech was one of the first languages into which this extremely difficult work was translated - well, partially translated. Only Anna Livia Plurabelle made it into Czech. Adolf Hoffmeister, a Czech translator of English literature, asked Joyce in person to be allowed to translate Finnegans $W$ ake. Later, in his writings, Hoffmeister described the meeting with Joyce as a "war summit". Joyce literally drilled his translators (not just Hoffmeister) on possible translations of various passages from Finnegans Wake. Hoffmeister felt as a "pupil" who would need to take his "final exam", which he may fail or pass. Hoffmeister passed Joyce's test, but not without a powerful - even thundering warning from the author: "I do not wish to be translated, I have to stay as I am, only expressed in your language. [...] In your land, there are many rivers. [...] You can break them up into living words, which were in the beginning, when God was the word. Create a language for your land according to my image" (cited in Woods, AAASS Conference 2004: 2, my italics, my emphasis). For comparison, here is John 1:1-3: "In the beginning was the Word, and the Word was with God, and the Word was God. He was in the beginning with God. All things were made through him ...” Joyce's, or Kundera's word must remain as it was created even when translated. Yet, Tim Parks rightly asks "who wrote the Milan Kundera you love? 
TranscUlturAl, vol.1,3 (2010), 30-42.

http://ejournals.library.ualberta.ca/index.php/TC

Answer: Michael Henry Heim.” In Joyce’s case, Hoffmeister with his colleagues bring Joyce, if only partially, to Czech readers thanks to their wonderful translation. Parks aptly illustrates this contradiction when he writes: "The translator should do his job and then disappear. The great, charismatic, creative writer wants to be all over the globe. And the last thing he wants to accept is that the majority of his readers are not really reading him" (The Observer, April 25, 2010). It is particularly interesting to note Joyce's expression "I do not wish to be translated". Joyce overtly addresses the organic unity between the author and his creation. He, Joyce, by way of his creation, does not wish to be translated. As we will see, it is not difficult at all to show the same organic unity in Kundera's case. Now, it is understood that this wish has nothing to do with the author's work not being disseminated and read all over the world; on the contrary, actually. What is at stake, from Joyce's or Kundera's point of view, is the authenticity of the author's words. And this leads to Parks's point vis-à-vis Kundera - even though it is the translator's job to translate, the resulting translation must remain authentic to the author. Parks points to an irony, which seems to escape god-impersonating authors. Kundera is very clear in his "Author's Note" (Žert) when he states that he wants all his books in the French version to have "the same authenticity as the Czech version" (1996: 325, my translation). I should note here that the Czech word for "version" Kundera uses is podoba, which also means "likeness", which is always connected to an actual original image. What does Kundera mean when he demands "the same authenticity"? With some help from dictionaries, a closer look at "authenticity" could prove helpful.

Both my web dictionary and hard-copy dictionary refer me immediately to the adjectival form, "authentic". The wordnetweb.princeton.edu/perl/webwn page offers many descriptions and expressions; I find the following to be most relevant:

1) authentic - "reliable information"

2) authentic - not counterfeit or copied; "an authentic signature"; "a bona fide manuscript"

The New Lexicon Webster's Encyclopedic Dictionary of the English Language (1988) offers a sample of near-synonyms: "authentic: genuine, true, reliable". There are two closely linked issues; one, the authenticity of the work; second, the authenticity as it relates to the author. These issues are two sides of the same coin, bonded together in a fluid way difficult to disjoin. But I will do my best for the sake of clarity. Keeping in mind Kundera's strong stance towards authorial control and ownership of his works, the following line of thought seems fitting: if a 
TranscUlturAl, vol.1,3 (2010), 30-42.

http://ejournals.library.ualberta.ca/index.php/TC

work is authentic, it is reliable, true and genuine. It is not copied, so it must be original, first or primary. It is the work originated by its author, its creator. The author as the creator, or God, owns his creation. The creator wants his work to be and remain the way s/he intended. The creator does not wish for his creation, his own extension, to be altered, modified or transformed in any way. Or, paraphrasing Kundera (Testaments Betrayed), no author's work should be betrayed by translators. The work of an author is a testament just as the Bible is a testament; this is the book of books, not to be altered and not to be transformed in any way. It is the first, the primary, there was nothing before. It is the Word of God. Once the author holds his creation, the author uses his own signature to authenticate the work. Thus the author confirms, or ascertains, that this work is a bona fide manuscript (see the definition above), that it is reliable, not counterfeit or copied. However many 'copies' are printed, the actual, original author's word is not altered. "Do you read Kundera? Do you like Nabokov?" - here, it is the name, the author's signature we use to refer to their work as belonging to the author, particular to him or her. If I say "I like Kundera", I am referring to his original, authentic works and to his particular style and expression. In an overt way, this metonymy emphasizes the organic unity between the author and his creation.

The organic unity between Kundera and his works; his omnipresent voice and stance are best exemplified in the history of cascading English and French translations of his novel Žert (The Joke). However chaotic and jumbled it may seem, it is no joke (pun intended). The novel was originally written in 1967. In 1969, the first English translation by David Hamblyn and Oliver Stallybrass was published in London (Macdonald). When Kundera looked at the translation, he could not believe his eyes:

I open [the English translation] and I do not recognize [the book]: it has a different number of chapters! Somebody rewrote the entire book, divided chapters into smaller components, compiled them again in a different way, left out most of the meditative passages, especially those dealing with music. (1996: 324, my translation)

Indeed, if all these transgressions had been committed, no wonder rage seized Kundera! When Kundera commented on the Spanish translation, he expressed his dismay in a very concrete and physical way: "all the erotic passages had been amputated" (1996: 324, my translation, my italics). Even more so, when Kundera praises Heim's English translation of The Joke (thus invalidating the previous English translations), he proclaims: "[this is] the first valid and authentic version of a book that tells of rape and has itself often been violated' (Crain 1999: 45, my italics). For Kundera, it is not 'just' a matter of the written word. It is 
TranscUlturAl, vol.1,3 (2010), 30-42.

http://ejournals.library.ualberta.ca/index.php/TC

material, organic, physical, the word is Kundera/God who feels betrayed and violated. And so, Kundera writes an open letter of protest to the Times Literary Supplement where he complains about all the betrayals his translators have committed. The publisher then published The Joke again "in the correct version, but only a small number which was aimed at calming down the enraged author" (1996: 324, my translation). To complicate the matter even further, in 1969, another edition was published in New York (Coward-McCann). This American edition is based on the first English translation by Hamblyn and Stallybrass. However, the author is still not happy because, according to Kundera, this American edition edits his original for commercial purposes. In other words, it is still abridged to make it an easy read for the American audience. In 1983, a new translation by Michael Henry Heim seems to make Kundera very happy. It is in the preface to this translation where Kundera asserts that his work has been so often violated, thus emphasizing the palpable, organic unity with his work/creation. Alas, as we learn when yet another version is published in 1993 by Harper-Collins, Kundera concedes that even though he authenticated Heim's translation, he did not read it. By 1993, the authenticated Heim's 1984 version becomes, in Kundera's words, "not my text" (Crain 1999: 45). Kundera annuls, invalidates Heim's version and authenticates the 1993 version.

And so after a long, tiring, and challenging journey Kundera finally seems to find what he has been looking for in translations of his works - the same authenticity as his Czech original texts. It took no less than five editions! Who did he trust with this final, definitive, fifth version of English translation? Why, himself! Kundera used his own word-for-word translations of the original Czech text but he openly admits that working on this last translation he also helped himself with "fine solutions" and "faithful renderings" from the last two translations (Kundera 1984: x). In other words, the fifth definitive version is a veritable collage of previous and Kundera's own translations. His own intervention, his own active role and his own word finally guarantee that this is a bona fide manuscript, not counterfeit or copied. And to further substantiate and prove that this translation is indeed authentic, no translator is listed in this edition. The organic unity between the creator and his creation has been restored once more - by obliterating previous translators' work, even though Kundera admits to the use of their travails. From Kundera's point of view, what matters is the authenticity of the work, of his word, which can be ascertained only with his authentic signature. Even if Kundera helps himself to other translators' solutions, he deems 
Transc UlturAl, vol.1,3 (2010), 30-42.

http://ejournals.library.ualberta.ca/index.php/TC

them authentic since they are chosen and validated by him, the author. To say that Kundera does not trust translators and would never agree to any notion of the translator impersonating, however briefly, the author is only stating the obvious. There can be nothing in between Kundera/the creator and his creation. Since no translator is listed in this final edition of The Joke, the book bears only Kundera's name - the reader of this fifth English edition reads the authentic word as written by the author, represented by his authentic signature. Except ... the reader reads the text in English.

The history of The Joke in its French version bears the same marks of the omnipresent godlike author. La Plaisanterie was first published in Paris in 1968 (translated by Michel Aymonin). It wasn't until 1979 that Kundera had a first good look at the French translation:

That was a terrible blow. Žert was not translated at all, but rewritten! ... Not one sentence was as I wrote it, all sentences were ameliorated, often expanded, there were added metaphors, hundreds of metaphors, banal metaphors - clichés. (1996: 324, my translation)

Immediately, Kundera starts working on corrections in collaboration with Claude Courtot. In 1980, a new, corrected translation is out, but Kundera is still not happy. In 1985, a third version is published; this time, Kundera revises Aymonin's translation by himself. This 1985 version is, as Kundera states, definitive. As it turns out, however, and as has been commented and written upon many times, Kundera's own definitive translated versions of his originals are rather unfaithful. In Kundera's own hands, many passages are rewritten, changed or left out altogether. But - aren't these "transgressions" the reason why raged seized him upon reading the first translations of his works? Indeed, they are - and so another open letter is written. This time, by Allison Stanger (1997), who jokingly keeps the letter and the circumstances very topical. She wrote her "In Search of The Joke: An Open Letter to Milan Kundera” on April 1 ${ }^{\text {st }}, 1996$ (i.e. April Fool's Day), in Prague. Of course, the matter, and the letter, are no joke. When Stanger compares the definitive English version and the Czech 1967 original, she finds that more than fifty paragraphs were left out in the English version. Mr. Kundera did not respond, keeping alive the image of a recluse (he does not give many interviews as he believes the printed version always skews his answers). Plentiful discussions of his incongruous position ensued. Most discussed, of course, was the contradiction between his own translation practices and those he demanded from his translators. 
TranscUlturAl, vol.1,3 (2010), 30-42.

http://ejournals.library.ualberta.ca/index.php/TC

In 1999, however, Kundera did speak. When asked about his obsession with translations in an interview for Lingua Franca (1999, volume 9, No 7, by Caleb Crain), Kundera is surprised:

An undue obsession with translations? I can't say. ... My books lived their lives as translations; as translations they were read, criticized, judged, accepted or rejected. I was unable not to care about translation. (Crain 1999: 43)

Many of his books originally written in Czech are translated into other languages via French translations of their originals. Naturally, this may quickly lead to a further dissolution of the organic unity between Kundera and his works. Any poetic license or freer translations in the French version are then picked up by the next translator. Like the game of word telephone, other language versions based on the French translations of Kundera's Czech works are distanced and disconnected from the reliable original word signed, or authenticated, by the author. Understandably, Kundera wants to prevent publishing of non-authentic versions. To use Kundera's own words again, he does not wish to be amputated or violated. As Stanger notes in her "Open Letter", when Kundera worked through and retranslated French and English versions, which became definitive, he himself omitted many passages of the original Czech text. Kundera retranslated these versions, let us keep in mind, to correct the grave sins committed by unfaithful translators before him. To ascertain these versions as definitive, he authenticates the French one with "Achevé le 5 décembre 1965", and the English one with "Completed December 5, 1965". But wait! The definitive French version (with the many omitted passages) was published in 1985 and the English definitive version (also with the many omitted passages) was published in 1992. So unless the French or the English reader compares the translation with the original Czech, s/he trusts that indeed, this translation is reliable and authentic, based on the original text. Did then Kundera change his own original? Kundera does, in fact, admit in the preface to Heim's English translation of The Joke $\left(4^{\text {th }}\right.$ English edition, once authorized by Kundera, later rejected) that he did, indeed, alter somewhat the original Czech text when working on the French 1979 translation. As the omnipresent and omnipotent author, Kundera does as he sees fit. Next, even more confusion (the Tower of Babel comes to mind!). When approached by the Czech publishing company Atlantis, Kundera agrees to publish Žert with them in 1990. The original - the first - version from 1967 is the one Kundera authorizes for the Czech publisher.

What are we to make of this confusing publishing history of Žert? The passages omitted by Kundera (and previous translators) deal with very specific, culturally embedded issues. In 
TranscUlturAl, vol.1,3 (2010), 30-42.

http://ejournals.library.ualberta.ca/index.php/TC

addition, there are some other smaller changes, which further de-contextualize some culturally and politically specific matters. Since Kundera himself decides to omit these particular passages, then it is reasonable to assume that his goal is to render his works more digestible for the target audience even if it means that, as a translator, he himself does not produce a faithful translation while demanding near literal faithfulness from other translators. In fact, with every new definitive version, Kundera introduces changes into his texts. I am certainly not the first one to note this. In her excellent analysis, Woods (2001) suggests that in Kundera's case, everything is translation. Due to Kundera's many revisions and various definitive versions, the original becomes displaced and rewritten. I will go even further in proposing that, in fact, in Kundera's case it is not productive to even try to locate the "true" original. We may talk about various versions, but to think conceptually in terms of an original, displaced or not, and then of its consequent translations, is simply counterproductive. It is much more productive to think of Kundera's work in terms of authenticity. True, Kundera does not make it easy for his readers to know where to find the authenticity he demands; still, the notion of "original" is too static in this fast paced world of Kundera's translations.

In order not to get caught in a circular discussion (which, I have to admit is very difficult as Kundera's story itself is rather circular, moving ahead and then back in time) I have to address an issue that has been lurking throughout my exploration of Kundera's writing and publishing history - the critical writings and interpretations of Kundera's works. In true Kunderian spirit, this issue will introduce some further complexity into my discussion. However, only in juxtaposing Kundera's obsessive demand for authenticity and the fact that Kundera has had to rely on translations of his works do we get a glimpse of how displacing this reliance must have been for him especially with regard to interpretations of his works. Bugge notes that most notably in the 1980s Kundera was in the "habit ... of publishing his novels with a postscript offering an authoritative interpretation of the text". Bugge calls this practice "an explanatory overkill” (Bugge 2003: 8). Kundera worries that what is authentic and sounds "true" in Czech may be misinterpreted once translated into another language. Kussi observes that Kundera's knowledge of his dependence on translators has even affected his style,

inducing [Kundera] to make his expression clearer, more decisive, less subject to misinterpretation. [Kundera] once stated in a newspaper interview: "The need for translations prodded me to wash my tongue, to strip my words down to their most basic meaning." (Kussi 2003: 974)

This work is licensed under a Creative Commons Attribution 3.0 License 
TranscUlturAl, vol.1,3 (2010), 30-42.

http://ejournals.library.ualberta.ca/index.php/TC

In other words, Kundera does all he believes he can do to make it easy for his works to live as translations without being misinterpreted. This exemplifies his distrust towards those who translate, publish or write critically about his work. In fact, Kundera has always been concerned about the lack of respect for the author. In Testaments Betrayed, he complains:

That frame of mind [respecting the author] ... seems to be coming undone lately. If not, they couldn't accompany a toilet paper commercial with a passage from a Brahms symphony. Or be praised for publishing abridged versions of Stendhal novels. If there were still a frame of mind that respects the author, people would wonder: Would Brahms agree to this? Wouldn't Stendhal be angry? (Kundera 1995: 272)

This viewpoint, combined with the fact that Kundera's work has lived mostly in translation, makes for a very tight and explosive authorial control. When The Unbearable Lightness of Being was made into a film, Kundera disapproved: "Not my film". In particular, Kundera mentioned the "doleful monotony of film orgasms" (Crain 1999: 44).

As any translator knows, the semantic content of a work necessarily shifts when translated; it is literally moved into another frame of reference. Inevitably, there will be losses but also gains in the process. Kundera, on the one hand, rejects this shift. On the other hand, however, he quickly learns that an absolute faithfulness in translation is unattainable as his own translated texts prove. Here, finally, I can start unraveling this convoluted translationinterpretation muddle. The original/first Czech version of The Joke was written long before Kundera became famous and translated. As it was written, by the young author, the novel was perhaps intended for a more local readership. What Kundera intended by writing Žert he saw misinterpreted once translated into a different language and a different frame of reference. Once Kundera realized what transformation Žert had undergone in translation, it indeed must have come as a shock. Kundera's shock quickly turned to anger, prompting him to control and obsess over his work, his word, his intentions. Kundera, reworking the French translation, admits: "Then I understood from my own experience [...] what it means to be tortured by translation and what translation is; I understood the need to watch $[\ldots]$ translations of my own books" (1996: 325). French is Kundera's second language and the first time he took upon the role and the job of the translator was when he corrected the French translation of Žert. Understandably, it must have been a very tough job - a torture, indeed. But I believe the dominant nuance of the quote does not necessarily reflect the torture of the translator's job and responsibilities. Rather, it reflects Kundera's own, personal torment and torture when reading, as he sees it, all those unfaithful translations of his work, 
TranscUlturAl, vol.1,3 (2010), 30-42.

http://ejournals.library.ualberta.ca/index.php/TC

violating his creation. It is unbearable and the only thing he can do to remedy this torture is to make the translations his own again thus ensuring that his work will not be misinterpreted.

The misinterpretation of Žert when it was first translated unleashed Kundera's rage all over again. His strong stance regarding authorial intent and control affected Kundera's attitudes towards his rather sudden world-wide fame. Žert was written in 1967 when then Czechoslovakia was getting its political hopes high; unfortunately, the Prague Spring ended with the Russian invasion of Kundera's home country. This political dimension, according to the author, was not pervasively relevant to Kundera's Žert. However, the entire political circumstance was a big deal in terms of the rest of the world hoping for a change in that part of Europe. Kundera believed that it was this mood that affected the international reception of Žert. He talks about his struggles to control the foreign critical reception and interpretation in his author's note in the 1996 Czech Atlantis edition of Žert. The reception in general was great, but Kundera was wary of his sudden world-wide fame as his self-deprecating note demonstrates: "Žert was praised everywhere (how not to praise a translator, whose country was just invaded by Russian tanks!) (1996: 326). The historical situation became prevalent in the context of his fame and his works and he did not like it a bit. The reception of $\check{Z}$ ert in the Czech Republic made Kundera rather happy: "[In the Czech Republic], my novel was seen not as a political pamphlet, but as an 'existential novel'." (1996: 325). But the politicized foreign reception enraged him. Kundera explains in the 1990 author's note:

What enraged me were not just translations, but also critical interpretations. ... In an interview with Liehm in 1967 I said the same thing which ten years later I repeated ad nauseam in Paris: the historical situation is not the actual subject of the novel; for me, its meaning resides in the fact that it illuminates with a new, exceptionally intense light those existential themes that fascinate me: revenge, forgetting, gravity and triviality, the relationship between history and the person, distancing from one's own actions, the schism between sex and love and so on. (1996: 325)

His authorial intentions and expression are clouded by the historical context that Kundera does not consider to be crucial to his novel, his creation. He further complains:

[...] what was then written about Žert were just shallow political commentaries and lyrical exclamations. After all, it was not just my fate, but the fate of the entire art coming from our part of Europe. A work of art reduced to its mere political dimension was thus automatically eliminated from the context of the current art. ... from the beginning of my residence in France, I defended myself and others against this journalistic reduction, systematically and oftentimes fiercely. (1996: 326)

Kundera, therefore, fights unceasingly and fiercely against the fate that would reduce and betray his creation, his art, his “original expression [as] a unique individual” (1995: 272). He 
Transc UlturAl, vol.1,3 (2010), 30-42.

http://ejournals.library.ualberta.ca/index.php/TC

takes extreme measures and, in the 1980s, parts company with all his publishers (except Gallimard). Or, to use the thematic phrase, he casts out all the publishers who betrayed him. The accumulated shifts of his authorial intent resulting from translation and politicized foreign interpretation, at least in Kundera's eyes, were unacceptable. Translated and misinterpreted, his work becomes uprooted, loses its authenticity, its natural, or intended, audience. Kundera says as much himself in The Art of the Novel when discussing Broch's literary fate:

Of all the great novelists of our time, Broch is, perhaps, the least known. It is not so hard to understand why. He had scarcely completed The Sleepwalkers when he saw Hitler in power and German cultural life annihilated; five years later he left Austria for America, where he remained until his death. In such conditions, his work - deprived of its natural audience, deprived of contact with a normal literary life could no longer play its proper role in its time: gather to itself a community of readers, supporters, and connoisseurs [...] it was discovered (rediscovered) after a long delay. (1986: 65-66)

Kundera's circumstances were nowhere this dramatic, but in terms of his works, there are certain parallels. Indeed, those who are connoisseurs of Kundera's work, his natural audience, will tend to understand rather than misunderstand, or miss altogether, Kundera's authorial intent and the authenticity of his work. But can any author dictate and control his readers and their interpretation of the author's work? Of course not. Even Kundera himself, however controlling he is perceived to be, shows willingness to be open to interpretations of his works in the interview with Ian McEwan for The Granta in 1984.

When McEwan proposes that Kundera's characters are often sexually jealous and that, in fact, they love it and need it, Kundera is surprised: "That's an interesting idea, but to be honest I've never thought about it that way. I've got nothing much to add; you're right." (McEwan 1984: 32). When McEwan further suggests that "there is a collusion between the oppressors and oppressed, an intimacy that is almost sexual", Kundera continues to be openminded to the interviewer's interpretation: "It is true. You're absolutely right; I was not completely conscious of it. But it is true" (32). At this point, McEwan notes jokingly, somewhat disappointed with Kundera's agreeable answers: "It would be better for me to say some things that weren't true: you could deny them eloquently" (32). Ah! How we want Kundera to be conflicting and annoying. Alas, at least by 1984, the year of this interview, Kundera may have been shifting his own attitudes. Although I believe it is very safe to assume that Kundera is willing to shift his attitude only when he is in agreement. This, of course, echoes his translation style - if suitable, Kundera is "unfaithful" to his own work. 
TranscUlturAl, vol.1,3 (2010), 30-42.

http://ejournals.library.ualberta.ca/index.php/TC

McEwan's interview with Kundera reveals more intriguing material; Kundera's following thought on things remembered and forgotten proves crucial:

I am much more interested in the fact that each of us, consciously or unconsciously, rewrites our own history. We are constantly rewriting our own biographies, constantly bringing our own sense - the sense we want - to events. We are selecting and shaping - picking out the things that reassure and flatter us, while deleting anything that might possibly detract. To rewrite history, then ... is not an inhuman activity.

On the contrary, it is very human. (33)

Even though Kundera talks specifically about one's own history, it is not difficult to adapt the same thought to his own work. First, I am very happy to see that Kundera himself seems to concur with my suggestion that within the context of his work and his approach to translation, it is irrelevant to speak of an original since what we think of as "original" is being constantly rewritten. Second, this quote makes it quite obvious that Kundera, in stark contrast to the faithfulness he demands from his translators, is fully cognizant that rewriting is part of any expression. More than that, he acknowledges that rewriting is a continuous process. How then should we reconcile Kundera's "rewriting conjecture" with his denying any license to translators? The answer is in the quote - what we rewrite is our own history, nobody else's. In other words, Kundera's texts can be rewritten only by Kundera, by their own author. This takes me back to where I started - to Kundera's famous adage 'You're not in your own house here, my dear fellow". It is the organic unity between the creator/Kundera and his creation that prompts him to rewrite, select and shape as he sees fit.

Whether we like it or not, when Kundera translates his own works he is, by his own admission, rewriting them as well. Kundera considers this to be a very human activity and so, when he believes he needs to bring his sense to events, he rewrites, selects and reshapes, which, no doubt, annoys many. In the case of Žert, the unwanted political dimension that the novel accrued in translation bothered Kundera immensely. As first written in Czech, in its domestic frame of reference, this political dimension does not, according to Kundera, play an active role in the novel. And so Kundera rewrites and reshapes the Czech text for the foreign reader so that, Kundera hopes, the foreign reader will see Žert as its author intended. Kundera may be impersonating God, but at the same time, he is also carrying out a very human activity in his own house.

Kundera's practices have rubbed many hard working translators the wrong way - still, Kundera believes that the systematic and enraged defense of his creation has paid off. Kundera claims that it wasn't until some 15 or 20 years after Žert first came out in Czech, that 
TranscUlturAl, vol.1,3 (2010), 30-42.

http://ejournals.library.ualberta.ca/index.php/TC

the novel started its own artistic and literary passage - thanks to the fact that the political and historical environment of the first Czech edition is long forgotten and the novel's current reception and critiques are written in a different historical frame of reference:

Today, those who regurgitate the news have long forgotten the Prague Spring and the Russian invasion.

Thanks to this oblivion Žert can, paradoxically, become again that which it has always wanted to be: a novel, nothing else but a novel. (1996: 326)

Instead of a formal conclusion, I will end my thoughts with the help of a quote. In a review of The Art of the Novel in The Guardian (June 10, 1988), titled "The Unbearable Knowingness of Kundera" (many of us seem to enjoy paraphrasing Mr. Kundera), I come across the following: "[Kundera] is at least as often thought-provoking as just plain provoking" and I suspect that, irritatingly to some, amusingly to others, Milan Kundera will remain so.

\section{REFERENCES}

Bugge, Peter. “Clementis’s Hat; Or, Is Kundera a Palimpsest?” Kosmas 16-2 (2003): 1-26.

Crain, Caleb. "Infidelity.” Lingua Franca 9-7 (1999): 38-50.

Kundera, Milan. The Art of the Novel. Trans. Linda Asher. New York: Grove Press, 1988.

---. The Joke. Trans. Michael Henry Heim. Harmondsworth: Penguin, 1984.

---. Testaments Betrayed. Trans. Linda Asher. New York: HarperCollins, 1995.

---. Žert. Brno: Atlantis, 1996.

Kussi, Peter. "Milan Kundera: Dialogues with Fiction." Companion to Contemporary World Literature 2 (2003): 971-975.

McEwan, Ian. "An Interview with Milan Kundera." The Granta 11 (1984)” 21-37.

Stanger, Allison. “"The Joke”: An Open Letter to Milan Kundera.” New England Review 18-1 (1997): 93-100.

Woods, Michelle. "Original and Translation in the Czech Fiction of Milan Kundera." Translation and Literature 10-2 (2001): 200-21.

---. 2004. "Transluding the Otherman". A conference presentation, Boston: AAASS Conference, 2004. 